\title{
Impact of Zakat Taxon Economic Recession Compared to Regular (State) Taxes
}

\author{
Dr. Tamam Odeh Abdullah Al-Assaf \\ School of Islamic Sharia, Jurisprudence And Its Principles, University of Jordan, \\ Jordan-Amman, P O Box 11942
}

\begin{abstract}
The Islamic obligation of Zakat plays a significant role in financing development, for Zakat has an investment role because it is oriented to generate and create new human productive capacities in society, in addition to its financing role through the means of expenditure. Furthermore, Zakat addresses and handles the psychological and objective reasons driving individuals to horde (amassment)and to refrain from participating in economic activity. Undoubtedly tax laws are not devoid of benefits to the state in case formulated according to well studied bases, where such taxes are imposed on segments of society which would not be harmed nor suffer distress as a consequence of such taxes, or which in principle should not be subjected to such taxes, given that they should basically be levied only on the wealthy, and should be imposed only in case the state is in need. And in all cases the present study focuses on highlighting the difference between Zakat as a religious obligation, and taxes as a legal obligation, and the impact of each of them on recession as an economic concept.
\end{abstract}

Keywords: Zakat, Taxes, Recession.

DOI: $10.7176 / \mathrm{EJBM} / 11-9-04$

Publication date:March $31^{\text {st }} 2019$

In the Name of Allah, the Compassionate, the Merciful

All praise to Allah the Lord of Creation, and peace and blessings upon our lord Muhammad, his family, and all his companions;

Introduction:

The purpose of the imposition of Zakat on the rich Muslims is the reinforcement of the structure of the Islamic state, the safeguarding of its interests, and bolstering its cohesion. This is the foundation which was built by Islam with a view to harmonizing between poverty and wealth, and also to protect the Zakat payers from the harm which the needy might perpetrate from among those, who if deprived of a portion of the wealth, would be hostile and belligerent towards the wealthy.

In general Islamic financial legislation based its financial resources on the foundation of meeting the expenses of public institutional activities, and the comfort of individuals and the community, and achieve the cooperation and solidarity underpinning social unity. In reality in case the quorum for Zakat is reached a reasonable and obligatory portion is deducted and this is equally applicable to all. ${ }^{1}$ By contrast states resort to prescribing taxes according to positive law, in order to achieve numerous aims and purposes which they seek; and undoubtedly the tax laws are not devoid of benefits to the state in case formulated in accordance with well studied bases, and which are moreover imposed on segments of society that are not harmed or that do not sustain hardship as a consequence, or essentially are taxes that should not have been imposed on them; given that they should only be imposed on the rich, and should be imposed only in case the state is in need. And in all cases this study focuses on studying the difference between Zakat as a religious obligation (for Muslims), and taxes as a worldly obligation, and the impact of each of them on recession as an economic concept (and phenomenon). Actually, numerous studies have treated Zakat and taxes through manifold and separate aspects, but I have found it appropriate to integrate them in a comparative study which highlights the impact of the Zakat obligation on recession in comparison to secular taxes.

\section{Part I: On the meaning (denotation) of Zakat and Recession (Kassad ar.).}

First: Concept of Zakat:

Zakat linguistically speaking:

growth and increase ${ }^{2}$ and is ascribed to purification, where Allah says: \{in order to purify them and sanctify them with it, \} Quran (9: 103), and the commentators said: purifying them with Zakat. Also, Zakkah denotes praise, and Tazakkah denotes giving charity. ${ }^{3}$

\footnotetext{
${ }^{1}$ See Ahmad, Mohammad Abd Al-Muttalib, Economic System in Islam, studies in Islam issued by the Higher Council for Islamic Affairs, supervised by Mohammad TawfiqOweidah, Issue number 47, p.102.

${ }^{2}$ Al-Hamawi, Abu Al-Abbas Ahmad Bin Mohammad Bin Ali Al-Fayyoumi, d. 770 Hijri, Al-Misbah Al-Munir FI Gharib Al-Sharh Al-Kabir, Al-Maktaba Al-Ilmiyyah -Beirut Part 1, p.254

${ }^{3}$ Al-Razi, Zein Eddin Abu Abdullah Mohammad Bin Abu Baker Bin Abdel Qader Al-Hanafi Al-Razi, d. 666 H., Mukhtar Al-Sihah, edited by Yousef Al-Sheikh Mohammad, Al-Asriyyah Library-Al-Dar Al-Namudhajiyyah, Beirut-Sidon, $5^{\text {th }}$ ed., 1999 A.D., p.136.
} 
And Zakat as a term: it is the name of a portion of wealth which a Muslimgives at a specified time to a group along with the an intention (Niyyah ar.); because wealth grows by dint of the blessings of paying the Zakat and its payer avails of the blessings of Allah.

Relationship between the Linguistic and Terminological Meaning:

It is, in the religious connotation, a cause of the growth of the wealth on which the Zakat is given and a purification of the giver from sin.

Zakat is obligatory: that is, it is a categorical obligation according to the Holy Quran, the correct Sunnah of the Prophet and the consensus (ijma`a ar.) of the Muslims. The Holy Quran says: \{and give Zakat, \} Quran (2: 43); and the Sunnah, where the Prophet peace and blessings be upon him says: ["Islam is based on five (pillars): testifying that there is no true god except Allah and that Muhammad (pbuh) is His slave and Messenger; performing of Salat (Iqamat-as-Salat); the payment of Zakat; performing Hajj (pilgrimage) to the House [of Allah (Ka'bah)]; and Saum (fasting) during the month of Ramadan."]. ${ }^{2}$

And the interpretation of Zakat is underpinned by two laudable attributes, purification and growth; Allah (SWT) says: \{Take Sadaqah (alms) from their wealth in order to purify them and sanctify them with it, \} Quran (9: 103), and Allah (SWT) says: \{Say: "Truly, my Lord enlarges the provision for whom He wills of His slaves, and (also) restricts (it) for him, and whatsoever you spend of anything (in Allahs Cause), He will replace it. And He is the Best of providers." $\}$ Quran (34: 39). Thus, the Zakat giver avails of both purification from the impurity of sins, and also reward in this world and the Hereafter. ${ }^{3}$

\section{Second: Concept of Recession:}

Recession is a term in macroeconomics which is ascribed to any noticeable decrease, that is wide ranging, in economic activity and continues for several months, and specifically it is ascribed to any period in which the gross domestic product decreases for a period of at least six months, which is one of the stages of the economic cycle in which usually unemployment rises and in which the value of investments and corporate profits declines. And as a result of recession there is a decline in production, prices, employment and also revenues, and during the period of economic recession monetary liquidity contracts and many companies and institutions go bankrupt and thus many lose their jobs. ${ }^{4}$

\section{PartII: Relationship of Zakat to Development in Islamic Economics:}

The Zakat duty plays a significant role in financing development where it provides an immense or renewable financial resource year after year, for it is an obligation due upon wealth that is wholly owned by a free Muslim, and where debt is not owed upon it, once quorum is reached, and a lunar year (hawl) has lapsed, and according to the conditions of Zakat a surplus accrues, and in fact the accrual increases along with the development and progress of society, where it is one of the foremost financial institutions in Muslim society, and plays a main role in achieving the objectives of solidarity and social security, and the redistribution of income between Muslims. Moreover, this benevolent institution has other significant effects on the process of economic development where it may be considered to be one of the means of financing development in Islamic economics.

Actually, Zakat has an investment role, because it is directly oriented to generate new human productive capacities in society ${ }^{5}$ and it is likewise the principal means for accumulating social capital in Muslim societies and, moreover, Zakat plays a role in enhancing the levels and rates of investment; given that the owners of wealth would be keen not to keep their property in an unproductive state, and would make the economic actors to continue to produce even if losses are incurred so long as such reduces the rate of Zakat imposed on the invested wealth.

Moreover, Zakat has a financing role through the methods of spending, for it plays a role in making the poor own means of production, such as providing them with housing, or machinery to work with, or wealth to trade with. And so long as it is permissible to collect Zakat in the form of capital goods it is permissible to distribute it in the form of capital goods, which become production tools in the hands of the poor. ${ }^{6}$

Setting the quorum of Zakat (Prescribed minimum amount liable to Zakat) at a level that only assures the basic needs, guarantees the flow of an abundant amount of Zakat, and its increase throughout the inflow of new wealth involving quorum, with the start of the development process, and the rise of the economic level of

\footnotetext{
${ }^{1}$ Al-Hattab, Shams Eddin Abu Abdullah Mohammad Bin Mohammad Bin Abdel Rahman Al-Trabulsi Al-Mughrabi, 954 H., Mawaheb Al-Jalil Fi SharhMukhtassar Khalil, Dar El Fikr, $3^{\text {rd }}$ ed., 1412 H., vol.2, p. 255

${ }^{2}$ Ahmad, Abu Abdullah Ahmad Bin Mohammad Bin Hanbal, (d. 241 Hijri), Musnad Al-Imam Ahmad Bin Hanbal, edited by Shu aybArna`outAdel Murshid, and others, Mu`assassat Al-Risalah, $1^{\text {st }}$ ed, 2001, H. 19220, $1^{\text {st }}$ ed., 2001 A.D., H.1922, Vol. 31, p.550..

${ }^{3}$ Al-Hanafi, Abu Baker Bin Ali Bin Mohammad Al-Haddadi Al-Abbadi Al-Zubaydi Al-Hanafi, d.800H., Al-Jawharah Al-Nayyirah, AlKhayriyyah Printing Press, $1^{\text {st }}$ ed., 1322H., vol.1, p.113.

${ }^{4}$ See www.babonej.com, Taher, Jamil, Al-Asfour, Saleh, Unified Manual of the Concepts and Terms of Planning in the Gulf Cooperation Council States, $1^{\text {st }}$ ed., 1996 A.D., Arab Planning Institute in Kuwait, p.181.

${ }^{5}$ IbnUbayd, Dr. Mohammad Ali Al-Qari, Overview of Contemporary Writings on Development, Symposium on the Contribution of Islamic Thought to Modern Economics, Cairo, $1^{\text {st }}$ ed., 1992, p. 364 quoted from ShawqiDunya (12/281).

${ }^{6}$ IbnUbayd, Dr. Mohammad Ali Al-Qari, Overview of Contemporary Writings on Development, Symposium on the Contribution of Islamic Thought to Modern Economics, Cairo, $1^{\text {st }}$ ed., 1992, p. 364 quoted from ShawqiDunya (12/281).
} 
increasing numbers of the members of society.

Thus the Zakat obligation is renewed at the start of every lunar year (Hawl), and with every harvest new resources are available for development, not just one year after the other, but during the single year given that the beginning of the year differs from one Zakat giver to the otherand this saves the development process from the risks of the deficiency of financing resources, and from the peril of consummating them from abroad, which would hinder the growth of existing investments, and in fact confers on the whole economy confidence in financing resources, which is emphasized one year after the other. ${ }^{1}$

The amount of Zakat imposed on wealth requiring Zakat ranges between a tenth, and half a tenth insofar as what was irrigated by rainfall, rivers and springs, even if a tenth, and half a tenth for what is irrigated by waterwheel and sprinkler, and a quarter of a tenth for gold and silver, and for commercial merchandise of all kinds. And this source is considered significant and is not less than (2.5\%) of every growing wealth in society. And this source naturally increases as the economy grows, and is annually renewed, and thus saves the economy from economic quakes, and protects it from trade cycles, where there is a continual rectification of economic variables, without awaiting reaching a cumulative situation that is difficult to remedy. ${ }^{2}$

Moreover, Zakat is distinguished by a designation of its sources, where Allah the Legislator has specified its objects of expenditure. This specifying or particularization contributes to an increase in public revenues, and thus the economists of positivist thought call for applying it in developing countries. This represents an emphasis on incentivizing full payment of zakat, and also an emphasis on the surplus of its returns. Also, what adds to the importance of Zakat as a resource for development, is the underlying faith which spurs individuals to endeavor to pay their zakat in full. Moreover, it prevents any who might consider resorting to trickery to evade the duty of zakat, whereby it is collected in full.

What further corroborates the abundance of zakat as a source for financing development is the low expenses of collecting it, whereby it is not in excess of the cost (and much less actually); where the zakat collectors avail of a share of one eighth which is prescribed and specified by Allah (SWT), and not more, and thus there is no substantial deduction from the zakat collected. ${ }^{3}$

\section{Part III: Role of Zakat in Preventing Hoarding (amassment):}

And resultant from the Zakat's indirect financing of development is the prevention of hoarding, where this blessed step is manifested in imposing Zakat every Hawl (lunar year), insofar as the amount of the quorum of liquid cash whether its owner grew it in reality or not, and this is the best plan to overcome the hoarding and Habs of wealth (hold of funds), which is a scourge that economists have found it daunting to remedy. Thus there emerged the Islamic view represented in the imposition of $2.5 \%$ Zakat annually which would incentivize the individual to grow and harness his wealth, thereby generating regular income, otherwise the Zakat would erode the wealth with the passage of time. This is why the Prophetic Traditions have urged trading with the wealth of the orphans so that it is not depleted, and this urging is the growing of the wealth of the orphans in particular because it is assumed that a person would not neglect his own wealth and would not develop and grow it, as a corollary of the personal motivation and desire for wealth. As to the orphans their wealth is in the hands of custodians who might neglect to grow it intentionally or out of laziness. Thus the Prophetic command emerged entailing the obligation of developing this wealth in order to protect it from diminution and depletion. And given that the percentage for money is $2.5 \%$, it follows that it should be grown in a manner earning profits in excess of this ratio, and this must spur economic thinkers to seek new horizons for the growing and development of wealth, and to seek the best means for legitimate earning of money, which would accommodate payment of Zakat and defray personal and family expenses whilst also contributing to dealing with the other burdens of society. ${ }^{4}$

The Zakat imposed on growing wealth entailing quorum and where the Hawl (lunar year) has lapsed might involve the peril of the diminution of capital year after year, and indeed to perish within a period less than forty years; given that it is obligatory to pay a portion of wealth in Zakat annually not less than one-fortieth of the entire wealth of the nation, while not growing capital means deducting a fixed proportion from a diminishing reservoir. In this connection Anas Bin Malek reported that the Messenger of Allah peace and blessings be upon him said, "Trade in the wealth of the orphans so that Zakat does not erode it."

Based on the foregoing it becomes clear that payment of Zakat is an incentive for investing wealth, so that its payment is derived from the profits rather than the capital, in addition to seeking lawful profit, after purifying the wealth.

${ }^{1}$ Mashour, Ni mat Abdel Latif, Zakat and the Financing of Development, Research Papers of the Symposium on the Contribution of Islamic Thought to Modern economics, Cairo, 1992, $1^{\text {st }}$ ed., p.681.

${ }^{2}$ Ibid, p.682.

${ }^{3}$ Ibid, p.682.

${ }^{4}$ Al-Qaradawi, Yousef, Role of Zakat in Treating Economic Problems and the Prerequisites for its Success, ${ }^{\text {st }}$ ed., Dar Al-Shurouq, 2001A.D., pp.55-56.

${ }_{5}^{5}$ Al-Tabarani, Abu Al-Qassem, Suleiman Bin Ahmad Bin Ayyoub, d.360H., Al-Mu jam Al-Awsat, edited by Tariq Bin Awadallah Bin Mohammad, Abdel Muhsin Bin Ibrahim Al-Hussein, Dar Al-Haramayn-Cairo, aprt 4, p.264. 
And Zakat treats the psychological and objective reasons spurring individuals to hoard and to refrain from partaking in economic activity; where the Zakat rules and principles are a guarantee to any who are deprived of strength and wealth: for it is an entitlement for any afflicted by personal conditions such as weakness or incapacitation or old age, which led to lack of material sufficiency resulting from his own work, whether he was unable to fulfill his basic needs wholly or partially, or as a result of his full-time dedication to the pursuit of knowledge which the Muslims have a need for. Moreover, it is the entitlement of those that face a commercial or personal disaster leading to loss of wealth. And the guarantee of Zakat of the sufficiency level diminishes the objective and psychological reasons for hoarding wealth to the lowest level, in addition to the fact that the hoarded wealth is subject to contracting purchasing power and diminution resultant from payment of Zakat, which reduces its value as an actual guarantee for facing the objective and psychological reasons for hoarding wealth. ${ }^{1}$

And among the functions of Zakat in Muslim society is its enabling the poor person to independently gain self sufficiency, where he would have a fixed source of income that would suffice him from seeking the assistance of others; hence the professional or merchant shall be given from the Zakat Fund what enables him to practice his profession or trade thereby earning what suffices him and his family on an ongoing basis.

Actually among the greatest obstacles to development is the existence of a wide gap between the members of a single society, where Zakat has a palpable impact on the redistribution of wealth, as well as narrowing the income gaps, such through collecting Zakat from the rich and giving a portion of it to the poor, which would increase their consumption levels, and would in turn lead to enhancing active demand and would also enhance demand for consumer goods and thus bolster consumer industries, and would also lead to the marketability of production goods utilized in the manufacture of consumer goods and thus production would increase, and by corollary new job opportunities would be generated. ${ }^{2}$

Actually Zakat is considered an essential source of finance in Islamic economics, such through directing a portion of the Zakat collected towards establishing investment projects needed by the poor and the indigent, who are employed in them, and who are empowered thereby, and it is likewise admissible to utilize a proportion of it to purchase the tools of production and to give ownership of them to the ordinary workers who are entitled to Zakat. $^{3}$

\section{Part IV: Impact of Zakat on Business}

It is known in economics that the process of redistribution of income mitigates the intensity of the income gap, and this has a substantial influence on remedying unemployment.

Actually Zakat transfers units of the incomes of the wealthy to the poor, and it is known that the rich are characterized by a marginal propensity to consume, and have a rising marginal propensity to save, ${ }^{4}$ and this results in an important outcome, namely that the Zakat collected would be given to a segment of society whose consumption curve rises, and this would in turn lead to an increase in active demand, which would result in rising demand for consumer goods, and hence the consumer industries would be bolstered, and this would lead to the promotion of marketability of productive goods utilized in the manufacture of consumer goods, and this would lead to a rise in production, and likewise the creation of new job opportunities. ${ }^{5}$

Actually, Islam is averse for wealth to be monopolized by the wealthy of the nation, and desires for wealth to be held in the hands of the greatest number possible to be spent on purchasing the necessities of life for such number of people, thereby enhancing demand for goods and also enhancing production and creating abundant employment, and thus the cycle of life, business, production and consumption would proceed in a continual and natural manner, and also for the sake of achieving balance and equilibrium and narrowing gaps between the classes. $^{6}$

\section{Part V: A New View of the Impact of Zakat on Investment.}

Given that the investment process demands favorable conditions pervaded by security and stability, Zakat is actually considered among the foremost factors leading to the presence of a suitable investment climate. Actually Islamic economics has provided social security and general guarantees for losses to which the investor may be exposed, and which he is powerless to act upon, where those in debt are entitled to a share of Zakat to face such

\footnotetext{
Mashour, Zakat and Financing Development ar., p.690.

${ }^{2}$ Hayat, Nawi, Contribution of Zakat to Reducing Unemployment ar., a field study on Annabah province for the period (2204-2012), the Second International Scientific Conferences on the Role of non-profit Islamic Financing in Achieving Sustainable Development, 2013 A.D., University of Saad Dahlab in Al-Blida, Algeria, p.8.

${ }^{3}$ Al-Sarahneh, Jamal Hassan Ahmad Issa, The Problem of Unemployment and Dealing with it, A Comparative Study between Fiqh and Law, Al-Yamamah for Printing and Publishing, Damascus-Beirut, $1^{\text {st }}$ ed., 2000 A.D., p.277.

${ }^{4}$ Al-Sarahneh, Jamal Hassan Ahmad Issa, The Problem of Unemployment and Dealing with it, p.275, quoted from Ibrahim Fuad Ahmad the Economic Impact of Zakat, Wa y Al-Islam Journal, issue number 134, 1976 A.D.

${ }^{5}$ Al-Assal, Ahmad Mohammad, Economic System of Islam ar., p.115.

${ }^{6}$ Abdel Aal, Ahmad Abdel Aal, Social Solidarity in Islam, Arab Publication and Distribution Company, 1997, p.116.
} 
conditions. ${ }^{1}$ On the authority of Mujahid, he said: "Three among the indebted: a man who lost his property due to floods, and a man whose property was subject to fire, and a man who has children but does not have wealth he deserves to be loaned and for his family to be supported."2 And according to Mohammad Bin Ali he said: "AlGharim is the indebted whose debt is not the result of excessive spending, where it is incumbent on the imam to pay his debt from the public treasury." 3 This means that giving the borrower who is incapable of paying his debtand this is general and includes all production and consumption loans- or the debtor who experiences disaster is entitled to the share of the debtors from the Zakat which achieves sublime meanings including:

- Making the individual sense his dignity and restoring his self-confidence and protecting him from feeling despair by virtue of society standing by him in his tribulation.

- Enhanced business, production and investment activity resulting from the confidence of the business sector and business owners in the fact that any misfortune to which their projects will be exposed will be compensated for, and that those projects or enterprises will not collapse upon being exposed to some difficulties. ${ }^{4}$

On the other hand Zakat plays a direct role in encouraging investment spending, and this role is represented in the fact that Zakat was offered in the form of consumer goods at times and at others in the form of productive goods, where cattle and livestock were not just consumer goods but were also productive goods, given that the livestock was utilized in agriculture and the derivation of food and beverages and was also used in the production of raiment and furniture. ${ }^{5}$

Actually the Muslim jurists (Fuqaha) gave due regard to the investment aspect or attribute of Zakat. Thus AlNawawi says, "Our fellow jurists said that if a person had a profession he is to be given the wherewithal to practice his profession or the tools of his profession however small or great the financial value to a degree whereby his earned profits are almost enough for his self-sufficiency, and this varies based on the differences of professions, countries, ages, and persons." 6

\section{Part VI: Impact of Zakat on Saving.}

It is natural for individuals to save and invest in the Islamic economy. However, differentiating between savings and investments appears to be somewhat of unclear features in Muslim society. This is so because the decisions of saving and investment are not independent of each other to a great extent in Islamic economics, contrary to the secular economy, where the investment decision is characterized by independence of the saving decision, and each of the two categories of decisions is adopted by different people, and are governed by various factors.

Hence, in Islamic economics there does not arise to a palpable degree that divergence between savings and investments, and thus there is an avoidance of the main cause of economic fluctuations. And naturally the savings will not be equivalent to investment in case a part of the savings is hoarded. And the hoarded wealth is merely savings which were not converted to investments. And hoarding is simply an activity entailed in keeping money in the form of inactive cash reserves. And according to Islamic principles loaning money from those inactive reserves does not merit any monetary reward in the form of interest. Moreover, Islamic economics are averse to economic loss, and hence there is the endeavor to convert hoarded wealth to savings as a prelude to directing them towards investment through imposition of Zakat on the hoarded monetary balances.

Therefore, the Zakat system is considered among the foremost factors encouraging saving in the Islamic economy, and moreover, this system is characterized by the fact that it is anchored in psychological factors connected to belief in God Almighty, and is not grounded in material factors which are easily evadable, and this assures for Zakat to play its part in Muslim society.

On this basis the gap between saving and investment is significantly narrowed in Islamic economics as a result of the Zakat system. And given the keenness of Islamic economics to avoid the loss of resources it is imperative to direct savings towards productive uses, whether through the individual investing his wealth and facing the risks of profit and loss which accompany this investment, or through its payment based on partnership or Mudaraba (Speculation). ${ }^{7}$

Some economists are of the view that given that the marginal propensity for saving among the rich is higher than among the poor, and whereas Zakat is paid by the wealthy and received by the poor whose marginal propensity

\footnotetext{
${ }^{1}$ Al-Mishal, Khaled Bin Abdel Rahman, Theoretical Side of the Investment Function in Islamic Economics, Ministry of Higher Education, Imam Muhammad ibn Saud Islamic University, 2002.

${ }_{2}^{2}$ Ibn Abu Shaybah, Abu Baker Bin Abu Shaybah, Abdullah Bin Mohammad BinnIbraahim Bin Uthman Bin Khawasti Al-Absi, d.235H., AlMusannafF 'ilAhadithW'alAathar, edited by Kamal Yousef Al-Hout, Maktabat Al-Rushd-Riyadh, ${ }^{\text {st }}$ ed., 1409H., Hadith 10660 , part 2, p.424. ${ }^{3}$ IbnZanjawayh, Abu Ahmad Hamid Bin Mikhlid Bin Qutaybah Bin Abdullah Al-Khurasani, d. 251H., Al-Amwal: Dr. Shaker Dheeb Fayyad, publisher: King Faisal Center for Research and Islamic Studies, Saudi Arabia, $1^{\text {st }}$ ed., 1406 H., Al-Amwal Part 3, p.1104.

${ }^{4}$ Al-Mishal, Khaled Bin Abdel Rahman, Theoretical Side of the Investment Function in Islamic Economics, Ministry of Higher Education, Imam Muhammad ibn Saud Islamic University, 2002, pp.199-200.

${ }^{5}$ Ibid, pp.199-200.

${ }^{6}$ Al-Nawawi, Abu ZakariyyahMuhieddinYahya Bin Sharaf, d.676 H., Al-Majmu`Sharh Al-Muhadhab, Dar El FIkr., vol.6, p.194.

${ }^{7}$ Al-Mish`al, op.cit, pp.382-383.
} 
for saving is weak, hence it is expected for the general impact of Zakat to be a rise of overall consumption in the economy, that is a decrease in overall saving.

However, this conclusion appears at first sight to be correct but it has been the subject of precise criticisms which may be summarized as follows: ${ }^{1}$

1- The marginal propensity for consumption among low income groups is higher among the rich is a proposition that is not always true, while secular economic studies have not reached a categorical opinion concerning the impact of the redistribution of income on the size of overall consumption.

2- Moreover, Zakat is much of the time spent on raising the consumption of the poor, and indeed providing them capital with which they can work rather than consume, that is to say, in this case it is directed towards investment rather than consumption.

3- Three of the categories of Zakat recipients namely: \{and those employed to collect (the funds); and for to attract the hearts of those who have been inclined (towards Islam); $\}$ Quran (9:60), need not be poor, and hence it is not expected for their marginal propensity for consumption to be always higher than the Zakat payers.

4- Zakat fosters enhanced incentive to invest, thereby raising the level of overall income and employment concurrently while increasing the consumption of the poor. And it is not possible to categorically aver that the new ratio of consumption to income will be higher than what it was prior to applying Zakat.

5- The rise in the consumption of the poor who receive Zakat does not require by necessity the decrease in saving; because this increase in their consumption is expected to increase their productivity by improving their health and nutritional standard.

6- The rise in overall consumption as a result of implementing Zakat is a much anticipated consequence, and also the rise in overall income relative to the previous levels is also expected as a result of the impact of Zakat on investment, and the productivity of the poor. Thus it is not possible to aver categorically whether the ratio of overall consumption and overall saving to overall income will increase or decrease. ${ }^{2}$

Zakat is a specific obligation that is imposed on private property in order to achieve particular social and economic aims specified by the Holy Quran, and thus it is not a tax that provides the state with revenues in general. Moreover, distributing the returns of this obligation should be to one or more of the eight categories mentioned in the Holy Quran: \{As-Sadaqat (here it means Zakat) are only for the Fuqara (poor), and Al-Masakin (the poor) and those employed to collect (the funds); and for to attract the hearts of those who have been inclined (towards Islam); and to free the captives; and for those in debt; and for Allah's Cause (i.e. for Mujahidoon - those fighting in the holy wars), and for the wayfarer (a traveler who is cut off from everything); a duty imposed by Allah. And Allah is All-Knower, All-Wise.\} Quran (9: 60).

Moreover, Zakat plays a prominent role in redistributing income and wealth. And in view of the fact that it is imposed on property and not solely on income, its ratio to income is much higher than its nominal rate which is equivalent to $2.5 \%$. And by corollary, it accounts for a portion of the annual national income that is amenable to redistribution to a point where it is possible to aver that history has not known, in any nation, Zakat as an established entitlement of the poor to the wealth of the rich which recurs every year and does not permit any authority the right to reduce it or to deprive those that have rights to it. ${ }^{3}$

\section{PartVII: Impact of Taxes on Recession.}

Section I: Concept of Taxation: Taxation is basically mandatory payments which are provided to the government, and is usually imposed on a wide spectrum of economic activities which range between consumption to income earning activities. ${ }^{4}$

Moreover, taxation is defined as a monetary obligation payable compulsorily to the state or to one of the domestic public organizations in a final manner to help the latter bear public expenses and obligation without the taxpayer availing of a specific benefit in lieu of paying the taxes. ${ }^{5}$

Based on the foregoing definition it becomes clear that taxes are distinguished by the following characteristics:

- Taxes are a monetary obligation: Tax is paid in the modern age in the form of money in harmony with the requirements of the economic system as a whole in view of the fact that all transactions are presently based on utilizing cash money whether in the public or private sectors, and given that public expenditures materializein cash liquid form it becomes necessary for revenues including taxes to be collected in cash money.

\footnotetext{
${ }^{1}$ Al-Mish `al, quoting Al-Zarqa, Anas, The Role of Zakat in the Public Economy and Fiscal Economy, a study published among the papers of the First Conference for Zakat, p.285.

${ }^{2}$ Ibid, p. 286 .

${ }^{3}$ Qahf, Mundher, Islamic Economics, Science and System, pp.22-23.

${ }^{4}$ Tax Burden in Jordan-Reality and Horizons, Hawiyyah Center, Jordan Independent Economy Watch, 2015 , p. 2.

${ }^{5}$ Al-Mahayni, Mohammad Khaled, Lectures in Public Finance, the National Institute of Public Administration-Preparatory Session, 2013 A.D., p.47.
} 
- Tax is paid compulsorily: This means that an individual is not free to pay or not pay taxes but is rather compelled to pay them to the state, where the element of compulsion is palpable by virtue of the independence of the state in laying down its legal regulations insofar as determining the tax base, rate and method of collection, without referring in so doing to the persons who are obliged to pay tax.

- Tax is paid in a final manner: What is intended here is that the person who undertakes to pay tax, does so to the state in a final manner, whereby the state is not obliged to reimburse him subsequently.

- Tax is paid without a return: What is meant by this attribute is that the taxpayer who pays tax does not avail of a direct return, or a particular benefit from the state when he paid it, even though this does not negate the fact that the individual could benefit from theservices provided by the state by means of the various public facilities inasmuch as he is a member of a community, and not as a person obligated to pay tax.

- Taxation enables the state to achieve public benefit: The state that is not obligated to provide a particular service or a particular benefit to the taxpayer; in fact it obtains the collected taxes to finance its public expenditures in the various sectors thereby achieving public benefits for society, and moreover, the taxes are now utilized to achieve economic and social purposes, such as the use of progressive income tax to redistribute income, and mitigate gaps between social classes, while custom taxes are imposed on imports to protect the national industries, and taxes might be imposed to mitigate consumption, and to encourage saving to accumulate surpluses for purposes of economic development. ${ }^{1}$

\section{Section II: Effects of Taxation.}

Imposition of taxes produces several effects, most importantly:

1- Decrease in the purchasing power of the consumer, which is available to him depending on the taxes that he paid, whether on his personal income, or on the purchase of goods and services.

2- The producer is inclined to particular economic activities that mitigate the tax burden, which leads to reducing economic efficiency.

3- Increase the cost of production, which leads to increasing the sellingprices which will influence the size of demand for the product upon offering it in the markets. ${ }^{2}$

4- Based on economic theory, high taxes lead to slowing down economic growth due to the negative results stemming from high taxes on personal disposable income and corporate profits. And usually high tax rates on income mean lower levels of disposal income which ordinarily means lesser consumption. This also applies to companies, where the high tax rate on corporate income means lesser profits and this leads to diminishing possible investment usually financed by earned profits.

5- Moreover, an inchoate legislative environment associated with the tax system is a greater obstacle in the face of investors than the imposed ratios of taxes. Thus the greater the freedom of action granted to the government to increase tax rates without a new law the more the obstacles in the path of investors. And investors will not be interested in investing in a country which does not impose a tax system equally to all institutions and individuals. ${ }^{3}$

6- When examining the structure of taxes in Jordan compared to other countries, it appears evident that the Treasury of Jordan strongly depends on indirect taxes to generate a majority of the public revenues. In other words, the tax structure in Jordan is characterized by substantial imbalance where it inclines strongly to indirect taxes at the expense of direct taxes. This has considerable effects on the justice of taxation in Jordan as a result of the regressive nature of indirect taxation. And this means that the poorer segments in society pay a larger share of their income on indirect taxes compared to the materially superior segments which save or invest more or consume goods and services outs the state which means that they spend a lesser share of their income on indirect taxes. ${ }^{4}$

7- Despite the continual increases in taxes and fees, the standard of services did not develop commensurately with the enhanced public revenues. This is the result of the government allocating most of its budget to current expenses (salaries and compensations) and does not sufficiently spend on capital expenses, which are a foundation for expanding public services, and improving their quality. And based on official statistics, the share of capital expense from public expenses declined in the long term. This is despite the high rate of economic growth realized in the previous decade, and prior to the onset of the global economic crisis, and according to the World Bank, the Government of Jordan followed a fiscal policy

${ }^{1}$ Ibid, p.48.

${ }^{2}$ Al-Tayyeb, Saud Musa, Impact of Direct Taxes (Income Tax and Profits) on the Gross Domestic Product,Dirasat Al-Ulum Al-Idariyyah ar., Vol. 40, Issue number 2, 2013 A.D., p.175.

${ }^{3}$ Tax Burden in Jordan, op.cit., p.15.

${ }^{4}$ Ibid, p.10. 
that is responsive to cyclical trends, and this policy was a main cause of macroeconomic instability. ${ }^{1}$

8- As to the influence of taxes on consumption and saving it is represented in the fact that taxes directly influence the amount of income of the taxpayers in descending order, and this is determined according to the tax rate, where whenever the tax rate is high the more it influences the amount of income and the opposite is true. This entails for the size of the consumption of goods and services to be influenced thereby: that is the tax rate on the level of prices, where the taxpayers and particularly those of limited and middle incomes have lesser income which spurs them to sacrifice some goods and services and particularly the luxury goods. Moreover, the size of income determines the degree of influence of taxation, for the high income is not much influenced by taxation, where the consumption of those segments is not reduced; because usually they pay taxes from their savings, while regarding those of low income, the effect of taxes on them is palpable, where the consumption of those segments decreases, especially concerning goods of flexible impact. ${ }^{2}$

9- The influence of taxes on saving depends on the distribution of the consumption of goods that are subject to taxation at the level of income. And whereas the largest amount of consumption is associated with those of low income because they represent the overwhelming majority, and hence the imposition of taxes on the goods consumed by this segment leads to a decline in consumption.. However, if one speaks of demand for goods concerning those of high income, the imposition of taxes on them will lead to the decrease in the saving of those. ${ }^{3}$

10 - As to the influence of taxes on production and distribution it is in a downward direction, and also production is influenced as a result of the taxes being influenced by the supply and demand of productive capital; for the supply of productive capital depends on saving and then investment, and just as decrease influenced saving and investment, this means a scarcity of productive capital and thus the amount of realized profit. And as a consequence of the imposition of taxes this could lead to the movement of the elements of production to other production branches that are of a lesser tax burden, and this affects economic activity. As to the impact of taxation on distribution it results in a redistribution of income and wealth in an unjust manner in favor of the rich classes at the expense of the poor classes, and this relates to the indirect taxes because they are a burden on the poor class. ${ }^{4}$

11- Taxes in the modern age represent the foremost types of public revenues upon which the state depends to defray public expenses, and the state compels individuals to contribute to the general burdens through imposing taxes on them in accordance with a particular technical system that is built on a set of principles and rules which govern the behavior of the state coupled with the commitment of individuals to pay the taxes, and the importance of taxes is attributable to the role they play in achieving the objectives of monetary policy, and to what they stir in technical and economic problems, and what results from them in economic and social effects. ${ }^{5}$

12- In case the imposition of taxes causes a deficiency in consumption, the latter causes a deficiency in production given that they are strongly intertwined, and hence the distribution of the effects resulting from taxes between them depends in terms of direction and extent on the flexibility of demand and the ease or difficulty of the process of the conversion of the factors of production from one sector to another. Moreover, taxes influence the supply of productive capital and demand for it.

13- The supply of capital depends on saving, and whereas taxes decrease income, hence they decrease saving, and hence capital, and particularly the direct progressive taxes, because their burden is borne by the social segments capable of saving, while indirect taxes contract the consumption of the segments of limited income, and hence this could lead to collective saving that is adopted by the state, and even though saving is essential for developing the backward and developing states, it places pressure on consumption despite its low level, and associated with this are social risks which require of the state to limit conspicuous consumption, and in such case it shall have targeted the high and middle incomes. ${ }^{6}$

\section{Conclusion}

\section{The foremost findings:}

- The duty of Zakat performs a significant role in financing development where it provides huge financial resources which are renewable year after another, for it is a duty that is associated with

\footnotetext{
${ }^{1}$ Tax Burden, op.cit., p.8.

${ }^{2}$ Rawiyah, Breik, Riyadh 'Eishoush, A Standard Study on the Impact of the Policy of Tax Collection on Economic Growth for the period (19902014), a Master's thesis, Faculty of Economic Sciences, Commerce and Management Sciences, Algeria, 2015A.D-2016A.D., p.31.

${ }^{3}$ Al-Jinabi, Taher, Science of Public Finance and Financial Legislation, University of Baghdad, Ministry of Higher Education and Scientific Research.

${ }^{4}$ Rawiya, op.cit., p.32.

${ }^{5}$ Mahayni, op.cit.p.48.

${ }^{6}$ Al-Jinabi, op.cit.pp.155-156.
} 
every wealth or property that is wholly owned by a free Muslim, which is devoid of debt, once quorum is reached, and thehawl (lunar year) has passed).

- Zakat actually has an investment role, because it is inclined directly to create new productive human capacities in society, given that those that own wealth are keen not to keep their assets unproductive.

- Zakat plays a financing role through the means of expenditure, for as long as it is permissible to collect Zakat in the form of capital goods it is also permissible to distribute them in the form of capital goods, whereby they would become production means in the hands of the poor.

- Zakat is distinguished by specifying its sources, where Allah the Legislator has determined its method of spending in a comprehensive manner.

- The Zakat is distinguished by the low cost of its collection, where it does not exceed the cost, given that those entrusted with its collection avail of a share of one eighth as specified by the Lord, and no more, and hence the Zakat is collected without a substantial deduction.

- Zakat treats the psychological and objective reasons driving individuals to hoard and to refrain from partaking in economic activity.

- Zakat has a palpable impact on redistributing income, and mitigating the intensity of income differences, such by means of collecting Zakat on wealth from the rich and paying a portion of it to the poor, which increases the marginal propensity for consumption, and this in turn leads to a rise in active demand in turn leading to an increase in demand for consumption goods which would contribute to a boom in consumption industries, and this would lead to a boom in productive goods utilized in the production of consumer goods thereby leading to a rise in production, thus creating more job opportunities.

- Zakat plays a direct role in encouraging investment expenditure, and this role is represented in the fact that Zakat was offered in the form of consumer goods at times and in other times in the form of productive goods.

- The Zakat system is considered among the foremost factors encouraging saving in Islamic economics, and this system is also distinguished by the fact that it is based on psychological factors connected to faith in God Almighty, and is not anchored in material factors that are easily evadable, and this guarantees for Zakat to play its role in Muslim society.

- High taxes lead to a slowdown in economic growth due to the negative consequences of high income tax on the personal disposable income and corporate profits.

- Thus the higher the tax rate the more considerable its impact on income and the opposite is correct. And this impacts on the volume of consumption of goods and services.

- The impact of taxes on saving is dependent on the distribution of the consumption of goods that are subject to taxation at the level of income. And whereas the highest volume of consumption is associated with low income groups because they represent the overwhelming majority, and hence the imposition of taxes on the goods consumed by this segment leads to less consumption. On the other hand, if demand for the goods is associated with the high income groups, the imposition of taxes on them will influence the saving of those and lead to its decline.

- Taxes lead to declining production and distribution, whereby production is influenced resulting from the impact of taxes on supply and demand for productive capital, for the supply of productive capital is contingent on saving and thence investment, and this means a dearth of productive capital and hence the level of realized profits.

- The supply of capital depends on saving, and whereas taxes reduce income, hence the taxes reduce saving.

\section{Sources and references:}

- Ahmad, Abu Abdullah Ahmad Bin Mohammad Bin Hanbal, (d. 241 Hijri), Musnad Al-Imam Ahmad Bin Hanbal, edited by Shu aybArna out-Adel Murshid, and others, Mu`assassat Al-Risalah, 1 ${ }^{\text {st }}$ ed, 2001, H. 19220.

- $\quad$ Ahmad, Mohammad Abdel Muttalib, Economic System of Islam ar., Islamic Studies issued by the Higher Council for Islamic Affairs, whose publication is supervised by Mohammad TawfiqOweidah, Issue number 47.

- $\quad$ Al-Jinabi, Taher, Science of Public Finance and Financial Legislation, University of Baghdad, Ministry of Higher Education and Scientific Research.

- Al-Hattab, Shams Eddin Abu Abdullah Mohammad Bin Mohammad Bin Abdel Rahman Al-Trabulsi ALMughrabi, 954 H., Mawaheb Al-Jalil Fi SharhMukhtasar Khalil, Dar El Fikr, $3^{\text {rd }}$ ed., 1412 H.

- Al-Hamawi, Abu Al-Abbas Ahmad Bin Mohammad Bin Ali Al-Fayyoumi, d. 770H., Al-Misbah AlMunir Fi Gharib Al-Sharh Al-Kabir, Al-Maktabah Al-Ilmiyyah-Beirut. 
- $\quad$ Al-Hanafi, Abu Baker Bin Ali Bin Mohammad Al-Haddadi Al-Abbadi Al-Zubaydi Al-Hanafi, d.800H., Al-Jawharah Al-Nayyirah, Al-Khayyirah Printing Press, $1^{\text {st }}$ ed., 1322H.

- Hayat, Nawi, Contribution of Zakat to Reducing Unemployment ar., a field study on Annabah province for the period (2204-2012), the Second International Scientific Conferences in the Role of non-profit Islamic Financing in Achieving Sustainable Development, 2013 A.D., University of Saad Dahlab in AlBlida, Algeria.

- $\quad$ Al-Razi, Zein Eddin Abu Abdullah Mohammad Bin Abu Baker Bin Abdel Qader Al-Hanafi AL-Razi, d. 666H., Mukhtar Al-Sihah, edited by Yousef Al-Sheikh Mohammad, Al-Asriyyah Library-Al-Dar ALNamudhajiyyah, Beirut-Sidon, $5^{\text {th }}$ ed., 1999 A.D.,

- $\quad$ Rawiyah, Breik, Riyadh 'Eishoush, A Standard Study on the Impact of the Policy of Tax Collection on Economic Growth for the period (1990-2014), a Master's thesis, Faculty of Economic Sciences, Commerce and Management Sciences, Algeria, 2015A.D-2016A.D.

- IbnZanjawayh, Abu Ahmad Hamid Bin Mikhlid Bin Qutaybah Bin Abdullah Al-Khurasani, d. 251H., AlAmwal: Dr. Shaker Dheeb Fayyad, publisher: King Faisal Center for Research and Islamic Studies, Saudi Arabia, $1^{\text {st }}$ ed., $1406 \mathrm{H}$..

- Al-Sarahneh, Jamal Hassan Ahmad Issa, The Problem of Unemployment and Dealing with it,A Comparative Study betweenFigh and Law, Al-Yamamah for Printing and Publishing, Damascus-Beirut, $1^{\text {st }}$ ed., 2000 A.D.

- Ibn Abu Shaybah, Abu Baker Bin Abu Shaybah, Abdullah Bin Mohammad Bin Ibrahim Bin Uthman Bin Khawasti Al-Absi, d.235H., Al-MusannafF ilAhadithW'alAathar, edited by Kamal Yousef Al-Hout, Maktabat Al-Rushd-Riyadd, $1^{\text {st }}$ ed., $1409 \mathrm{H}$.

- Al-Tabarani, Abu Al-Qassem, Suleiman Bin Ahmad Bin Ayyoub, d.360H., Al-Mu jam Al-Awsat, edited by Tariq Bin Awadallah Bin Mohammad, Abdel Muhsin Bin Ibrahim Al-Hussein, Dar Al-HaramaynCairo.

- Al-Tayyeb, Saud Musa, Impact of Direct Taxes (Income Tax and Profits) on the Gross Domestic Product, Dirasat Al-Ulum Al-Idariyyah ar., Vol. 40, Issue number 2, 2013 A.D.

- Tax Burden in Jordan-Reality and Horizons, Hawiyyah Center, Jordan Independent Economy Watch, 2015.

- Abdel Aal, Ahmad Abdel Al, Social Solidarity in Islam, Arab Publication and Distribution Company, 1997.

- IbnUbayd, Dr. Mohammad Ali Al-Qari, Overview of Contemporary Writings on Development, Symposium on the Contribution of Islamic Thought to Modern Economics, Cairo, $1^{\text {st }}$ ed., 1992, p. 364 quotedfrom ShawqiDunya (12/281).

- Al-Assal, Ahmad Mohammad, Economic System in Islam ar.,

- Qahf, Mundher, Islamic Economics, Science and System, pp.22-23.

- $\quad$ Al-Qaradawi, Yosuef, Role of Zakat in Treating Economic Problems and the Prerequisites for their Success, $1^{\text {st }}$ ed., Dar Al-Shurouq, 2001A.D.,

- Al-Mishal, Khaled Bin Abdel Rahman, TheoreticalSide of the Investment Function in Islamic Economics, Ministry of Higher Education, Imam Muhammad ibn Saud Islamic University, 2002.

- Mashoour, Ni mat Abdel Latif, Zakat and the Financing of Development, Research Papers of the Symposium on the Contribution of Islamic Thought to Modern Economics, Cairo, 1992, $1^{\text {st }}$ ed.

- Al-Mahayni, Mohammad Khaled, Lectures in Public Finance, the National Institute of Public Administration-Preparatory Session, 2013 A.D..

- Al-Nawawi, Abu ZakariyyahMuhieddinYahya Bin Sharaf, d.676 H., Al-Majmu`Sharh Al-Muhadhab, Dar El FIkr. 